\title{
Immunopathogenesis of acute lepromatous uveitis: a case report
}

\author{
P I MURRAY, M G KERR MUIR \& A H S RAHI \\ Moorfields Eye Hospital and Institute of Ophthalmology, City \\ Road, London EC1V 2PD
}

Accepted for publication 6 September 1985

\begin{abstract}
Summary Various immunological parameters were examined in a patient with acute anterior uveitis who was also suffering from lepromatous leprosy. The most significant abnormality detected was a reduction in a subpopulation of $\mathrm{T}$ lymphocytes known as suppressor cells, which occurred only during the acute attack and returned to normal once the attack subsided.

This finding leads to the speculation that acute anterior uveitis in lepromatous leprosy may be regarded as an intraocular component of erythema nodosum leprosum, precipitated by an imbalance of T-lymphocytes and probably mediated through immune-complex deposition in the uveal vasculature.
\end{abstract}

\section{Introduction}

Leprosy has the highest incidence of ocular complications of any systemic infection, and it is responsible for blindness in about $5 \%$ of those afflicted. ${ }^{1}$

Uveitis may occur in any form of leprosy but is commoner in the lepromatous form. It may be of 2 types: (a) chronic anterior uveitis in which there is a low grade bilateral uveitis associated with patchy or diffuse iris atrophy and progressive miosis. This is thought to have a neuroparalytic origin, ${ }^{2}$ and (b) acute anterior uveitis ( $A A U)$, which is less common than the chronic type, usually bilateral, and the aetiology is thought to be due to deposition of immune complexes within the iris. $^{3}$

One of the many systemic complications of lepromatous leprosy (LL) is a peculiar reactional state known as erythema nodosum leprosum (ENL). This is a form of vasculitis which can occur spontaneously but more of ten follows the introduction of chemotherapy. Histologically the lesions are characterized by an intense perivascular infiltration with polymorphonuclear leucocytes. The vessels in the centre of the lesion may show fibrinoid necrosis and endothelial swelling.

Correspondence to: Philip Murray, Moorfields Eye Hospital, City Road, London EC1V 2PD 
These histological appearances in conjunction with the demonstration of immunoglobulin, complement and mycobacterial antigen deposits around blood vessels in some ENL lesions have formed the concept that ENL is an immunecomplex mediated disease, similar to a type III Arthus reaction. ${ }^{4}$ Patients with ENL may develop an acute anterior uveitis and many of the other manifestations found in chronic serum sickness including fever, lymphadenopathy, albuminuria, arthralgia, orchitis and neuritis.

Mshana ${ }^{5}$ states that AAU as a complication of leprosy occurs only during ENL, and proposes that ENL is initiated by a decrease, absolute or relative, of suppressor T-cells. It was decided, therefore, to study various immunological parameters including T-lymphocyte subsets in the peripheral blood of a patient with AAU also suffering from LL. Any abnormalities detected might shed more light on the immunopathogenesis of acute anterior uveitis in lepromatous leprosy.

\section{Case report}

The patient, a 60-year-old man, had his lepromatous leprosy confirmed 24 years previously, 2 years after emigrating from India. At that time he had symmetrical peripheral nerve involvement of all limbs, marked nasal and palatal infiltration and stridor as a result of unilateral laryngeal leprosy. No ocular features were reported. He has had continuous treatment with daily dapsone $25 \mathrm{mg}$ and clofazimine $100 \mathrm{mg}$.

His ocular symptoms began 12 years ago with intermittent discomfort of both eyes, attributable to upper and lower lid trichiasis due to atrophy of the tarsal plates and overlying muscles. He became aware of a gradual deterioration of vision from his left eye. This was due to marked miosis that was resistant to mydriatic agents. Seven years ago he had an optical iridectomy which improved the vision from $6 / 24$ to $6 / 18$. His present attack developed with a 1-week history of a painful, red right eye with blurred vision.

The corrected visual acuities were right $6 / 12$, left $6 / 24$. There was marked bilateral atrophy of the lids which resulted in upper and lower lid trichiasis that induced a fine superficial punctate keratopathy. There were small discrete opacities in the anterior $1 / 3$ of the stroma in the supero-temporal quadrant of both corneae. Band keratopathy was more marked in the left eye. Both corneae had impaired sensation. The right eye had mild limbal injection but a dense fibrinous exudate and cellular reaction in the anterior chamber. The pupil was $2.0 \mathrm{~mm}$ in diameter. The left anterior chamber had a flare and no cells, a $1.5-\mathrm{mm}$ pupil that could not be dilated and an iridectomy in the infero-temporal quadrant. There was diffuse atrophy of both irides. Intraocular pressures were $7 \mathrm{mmHg}$ in each eye. The acute anterior uveitis responded to hourly dexamethasone $0 \cdot 1 \%$, atropine $1 \%$ qds over 1 month but a residual flare remained. 


\section{Laboratory investigations}

Venous blood was examined during the acute attack of anterior uveitis and during remission, 5 months later.

\section{LYMPHOCYTE PARAMETERS}

The following techniques have previously been described in detail. ${ }^{6}$ Briefly, lymphocytes were isolated by a standard density gradient technique using FicollPaque. Total number of T-cells were estimated by an E-rosetting technique using neuraminidase-treated sheep red blood cells. The number of helper and suppressor T-cells was measured by an indirect immunofluorescence technique after incubation with the monoclonal antibodies OKT4 and OKT8 (Ortho Diagnostics) respectively.

Table 1. Immunological parameters measured during the acute attack of anterior uveitis and in remission in a patient with lepromatous leprosy.

\begin{tabular}{|c|c|c|c|}
\hline Parameter & Acute attack & Remission & Normal values \\
\hline $\begin{array}{l}\text { Total lymphocyte } \\
\text { count }\left(10^{9} / 1\right)\end{array}$ & $2 \cdot 52$ & $2 \cdot 48$ & $1 \cdot 5-4 \cdot 0$ \\
\hline $\begin{array}{l}\% \text { E-rosetting } \\
\mathrm{T} \text {-cells }\end{array}$ & 58 & 55 & $65-75$ \\
\hline $\begin{array}{l}\% \text { Helper T-cells } \\
\text { (OKT4+ ve) }\end{array}$ & 37 & 37 & $36-43$ \\
\hline $\begin{array}{l}\text { Suppressor T-cells } \\
(\text { OKT } 8+\text { ve })\end{array}$ & 16 & 22 & $22-26$ \\
\hline $\begin{array}{l}\text { Helper/suppressor } \\
\text { (OKT4/OKT8) T-cell } \\
\text { ratio }\end{array}$ & $2 \cdot 31$ & $1 \cdot 68$ & $1 \cdot 54-1 \cdot 99$ \\
\hline $\begin{array}{l}\text { Serum immunoglobulins } \\
(\mathrm{g} / \mathrm{l})\end{array}$ & & & \\
\hline $\operatorname{IgG}$ & $18 \cdot 4$ & $20 \cdot 9$ & $6 \cdot 0-15 \cdot 0$ \\
\hline $\operatorname{IgA}$ & $6 \cdot 34$ & 6.97 & $0 \cdot 95-4 \cdot 0$ \\
\hline $\operatorname{IgM}$ & 0.925 & $1 \cdot 12$ & $0 \cdot 6-3 \cdot 0$ \\
\hline Antinuclear antibody & $\begin{array}{l}\text { + ve } 1: 10 \\
\text { dilution }\end{array}$ & $\begin{array}{l}\text { + ve } 1: 10 \\
\text { dilution }\end{array}$ & $15 \%+v e$ \\
\hline $\begin{array}{l}\text { Antismooth muscle } \\
\text { antibody }\end{array}$ & - ve & $\begin{array}{l}\text { + ve } 1: 10 \\
\text { dilution }\end{array}$ & $16 \%+v e$ \\
\hline $\begin{array}{l}\text { Antigastric parietal } \\
\text { cell antibody }\end{array}$ & $-v e$ & $-\mathrm{ve}$ & $3 \%+v e$ \\
\hline $\begin{array}{l}\text { Circulating immune } \\
\text { complexes }(\% \mathrm{IgG})\end{array}$ & $0 \cdot 25$ & $0 \cdot 55$ & $0 \cdot 08-0 \cdot 82$ \\
\hline
\end{tabular}


The values obtained were compared to those of a large group of healthy controls. All measurements (patient and controls) were performed by one of the authors (PIM).

The measurement of lymphocyte subpopulations was carried out the same day the blood was taken, because blood stored at $4^{\circ} \mathrm{C}$ is known to produce a low yield of E-rosetting and helper T-cells. ${ }^{7}$

CIRCULATING IMMUNE COMPLEXES (CIC)

CIC were precipitated by a standard polyethylene glycol (PEG) technique. ${ }^{6}$

\section{SERUM ANTIBODIES}

Circulating antibodies to nuclear material, smooth muscle and gastric parietal cells were detected by a standard indirect immunofluorescence technique.

\section{SERUM IMMUNOGLOBULINS}

Serum $\mathrm{IgG}, \mathrm{A}$ and $\mathrm{M}$ were measured using a standard rate nephelometric technique.

\section{Discussion}

Various immunological abnormalities have been reported ${ }^{8}$ in patients with lepromatous leprosy, including polyclonal hypergamma globulinaemia and autoantibodies against a wide range of antigens. It was not surprising, therefore, that raised IgG, IgA, antinuclear and antismooth muscle antibodies were found in this patient's serum.

The most important finding in this patient, however, was the abnormality in T-lymphocyte parameters. Although the total lymphocyte count was within normal limits, the total T-cell values during the acute attack and in remission (as measured by the number of E-rosettes) were decreased. During the acute attack of anterior uveitis the number of suppressor T-cells (TS) was found to be decreased but the number of helper T-cells (TH) was within normal limits, thus causing an increase in the helper:suppressor (TH:TS) T-cell ratio. During remission, however, the number of TS returned to normal as did the TH: TS ratio. Although only two samples were taken (during the acute attack and remission) the blood was drawn at the same time of the day on both occasions and the lymphocytes analysed immediately by PIM. Diurnal variation ${ }^{9}$ of lymphocyte subpopulations and the effect of temperature and storage ${ }^{7}$ were, therefore, eliminated. The reproducibility of the technique has been confirmed in a previous study ${ }^{10}$ which measured lymphocyte subpopulations repeatedly over a six-month period. 
Various T-lymphocyte abnormalities have already been described in leprosy. E-rosetting T-cell values have been found to be decreased in 2 studies, ${ }^{11,12} 1$ of which also showed an increase in B-lymphocytes. Tuberculoid leprosy appears to show no abnormalities in T-cell subsets, but lepromatous patients exhibit striking variations. ${ }^{13-15}$ Treated LL patients show normal numbers of TH and TS but untreated LL patients have raised numbers of TS and slightly reduced numbers of $\mathrm{TH}$ causing a decrease in the TH: TS ratio. It is interesting to note, however, that LL patients with ENL show decreased numbers of TS, thereby causing an increase in the TH:TS ratio. This abnormality is not permanent and in patients who remain free of ENL for a few weeks the TH:TS ratio returns to normal. The latter findings were also a feature in our patient.

Reduced numbers of TS (which have also been found in other ophthalmological conditions including Graves' ophthalmopathy, ${ }^{16}$ recurrent herpes simplex keratitis $^{17}$ and Mooren's ulcer ${ }^{6}$ ) may lead to unchecked helper T-cell activity resulting in the overproduction of serum autoantibodies, raised serum immunoglobulins and immune-complex mediated inflammation.

In a histopathological study of iris biopsies obtained during cataract extraction in patients with lepromatous leprosy, 13 out of 27 cases had histological evidence of active inflammation and the tissue was infiltrated by lymphocytes, plasma cells and mast cells. Five of these also showed evidence of vasculitis and perivasculitis suggesting that the disease may have started as an acute anterior uveitis. The vasculitis probably represents an immune-complex mediated reaction, although a type II or type IV allergic reaction following deposition of bacteria-derived antigens on the vascular endothelium cannot be excluded.

Although acute anterior uveitis in lepromatous leprosy occurs as a manifestation of ENL, raised circulating immune complexes (using a PEG precipitation technique) were not found in this patient. This finding is not unusual as many patients with nonleprous AAU also have normal levels of circulating immune complexes (CIC). The reason for this may be that immune complexes are either formed locally or appear only intermittently during the disease process and therefore may not be present in the circulation all the time. Recent studies ${ }^{18}$ have shown specific receptors for the Fc portion of the antibody molecule and for certain components of complement in the capillaries and along the basement membrane of the ciliary body. It is possible, therefore, that the uveal tract acting as an 'affinity column' could become a repository for phlogistic antigen-antibody aggregates irrespective of the level of CIC. Alternatively immune complexes may be generated within the uveal vessels by sequential binding of antibody, complement and circulating antigen leading to acute inflammation.

One can speculate from the findings in this case report that the immunopathogenesis of AAU in LL may be regarded as an intraocular component of ENL, precipitated by a reduction in TS and probably mediated through immunecomplex deposition in the uveal vasculature. 


\section{Acknowledgments}

We are grateful to Mr Peter Wright for allowing us to publish details of this case. We thank Mr J Prasad for technical assistance and Miss M Baines for typing the manuscript. This study has been supported by the Friends of Moorfields Research Fellowship Grant.

\section{References}

${ }^{1}$ ffytche TJ. Iritis in leprosy. Trans ophthal Soc UK, 1981; 101: 325-7.

${ }^{2}$ ffytche TJ. Role of iris changes as a cause of blindness in lepromatous leprosy. Br J Ophthalmol, 1981 65: 231-9.

${ }^{3}$ Hobbs HE, Harman DJ, Rees RJW, McDougall AC. Ocular histopathology in animals experimentally infected with Mycobacterium leprae and M. lepraemurium. Br J Ophthalmol, 1978; 62: 516-24.

${ }^{4}$ Wemambu SNC, Turk JL, Waters MFR, Rees RJW. Erythema nodosum leprosum: a clinical manifestation of the Arthus phenomenon. Lancet, 1969; ii: 933-5.

${ }^{5}$ Mshana RN. Hypothesis: erythema nodosum leprosum is precipitated by an imbalance of Tlymphocytes. Lepr Rev, 1982; 53: 1-7.

${ }^{6}$ Murray PI, Rahi AHS. Pathogenesis of Mooren's ulcer: some new concepts. Br J Ophthalmol, 1984; 68: 182-7.

${ }^{7}$ Murray PI, Rahi AHS. Effect of temperature and storage on lymphocyte subpopulations. Lancet, 1983, ii: 1373-4.

8 Wager O. Immunological aspects of leprosy with special reference to autoimmune diseases. Bull Wld Hlth Org, 1969; 41: 793-804.

${ }^{9}$ Ritchie AWS, Oswald A, Micklem HS, Boyd JE, Elton RA, Jazwinska E, James K. Circadian Variation of Lymphocyte subpopulations: a study with monoclonal antibodies. $\mathrm{Br} \mathrm{Med} \mathrm{J,}$ 1983; 286: 1773-5.

10 Murray PI, Dinning WJ, Rahi AHS. T-lymphocyte subpopulations in uveitis. Br J Ophthalmol, 1984; 68: 746-9.

11 Dwyer JM, Bullock WE, Fields JP. Disturbance of the blood T:B lymphocyte ratio in lepromatous leprosy. New Engl J Med, 1973; 288: 1036-9.

12 Nath I, Curtis J, Bhutani LK, Talwar GP. Reduction of a subpopulation of T lymphocytes in lepromatous leprosy. Clin exp Immunol, 1974; 18: 81-7.

13 Bach M-A, Chatenoud L, Wallach D, Phan Dinh Tuy F, Cottenot F. Studies on T-cell subsets and functions in leprosy. Clin exp Immunol, 1981: 44: 491-500.

${ }_{14}$ Wallach D, Cottenot F, Bach M-A. Imbalances in T cell subpopulations in lepromatous leprosy. Int J Lepr, 1982; 50: 282-90.

15 Mshana R N, Haregewoin A, Harboe M, Belehu A. Thymus dependent lymphocytes in leprosy. 1. T lymphocyte subpopulations defined by monoclonal antibodies. Int J Lepr, 1982; 50: 2916.

${ }^{16}$ Felberg N, Sergott R, Savino P, Blizzard J, Schatz N. Lymphocyte subpopulations in Graves' ophthalmopathy. Arvo Abstracts. Supplement to Invest Ophthalmol visual Sci. St. Louis: Mosby, 1983; 192.

17 Stelzer GT, Eiferman RA, Watson S. Alterations in T-cell subsets in patients with recurrent herpes simplex keratitis. Arvo Abstracts. Supplement to Invest Ophthalmol Visual Sci. St Louis: Mosby, 1983; 192.

18 Lowder CY, Lyon H, Char DH. C3b receptors in the human uveal tract. Arvo Abstracts. Supplement to Invest Ophthalmol Visual Sci. St. Louis: Mosby, 1983; 38. 